\title{
メイラード反応を利用したクロムなめし牛革の着色
}

\author{
大江 猛 ${ }^{* 1, \#}$ ・吉村 由利香*1, 島田 裕司*2
}

\section{Coloration of Chrome Tanned Leather by Maillard Reaction}

\author{
Takeru Ohe $^{* 1, \#}$, Yurika Yoshimura ${ }^{* 1}$, and Yuji Shimada ${ }^{* 2}$ \\ ${ }^{* 1}$ Osaka Municipal Technical Research Institute, 1-6-50 Morinomiya, Joto-ku, Osaka 536-8553, Japan \\ ${ }^{* 2}$ Okamura Oil Mill Co., Ltd., 4-5, Kawara-cho, Kashiwara, Osaka 582-0004, Japan
}

\begin{abstract}
Chrome tanned leather sheets could be colored in an aqueous solution containing reducing sugars, similar to the coloration of various foods containing both protein and reducing sugars, by the Maillard reaction. The obtained sheets showed yellowish or brownish color. Further reaction conditions, such as reaction time, temperature, and types of reducing sugar, were also investigated in this paper, where it was clear that their long reactions at the high temperatures $\left(>95^{\circ} \mathrm{C}\right.$ ) caused not only their deep coloration, such as dark brown, but also their serious contraction owing to thermal denaturation of their protein
\end{abstract}

(Received 3 April, 2014 ; Accepted 5 June, 2014)

\section{1. 緒 言}

牛革は, 革靴, 鞄, ベルト, ソファーなどの生活用品 から, 野球のグラブ, サッカーボールなどスポーツ用品, 太鼓などの楽器まで広い分野で利用されている。最近で は, より軽量で, 高強度, さらに, 安価に製造できる合 成皮革が牛革の代替として, ランドセルや革靴などに多 く利用されている。しかしながら，長期間利用した際の 合成皮革の品質低下や, 天然皮革に特有の手触り感や弾 力性などの風合いから, 自動車の内装材をはじめ高級品 を中心に牛革に対するニーズは依然として高い. 通常, 牛革の原料である牛皮には, 生前についた傷痕, 動物が 持つ㱀(しわ)や柄などがあり, 皮革製品が生産される際 に, これらは傷や污れとして商品価值を低下させる. そ のため, 傷や污れを消す目的で, 染料や顔料を用いて牛 革は着色されることが一般的に多い. 染料を用いた場合 には, 牛革内部にも着色されることから, 擦り傷に対し ても塗装がはがされない利点がある反面, 未固着の色素 やその分解物が牛革内部に残留し, 色落ちや色移りなど の染色堅ろう度が低下する原因となっている．顔料を用 いた場合には, 染料よりも簡便に着色できるが, バイン ダーで色素が牛革の表面に固着されているため, 軽微な 傷によっても塗装がはがされる.

一方, 食品の分野では, アミノ酸やタンパク質などの

\# corresponding author

*1 地方独立行政法人大阪市立工業研究所

*2 岡村製油株式会社
アミノ化合物とでんぷんやグルコースなどの糖質を含ん だ食品を加熱，あるいは長期間保管することによって， メイラード反応が進行し, 黄色から茶褐色の色素が食品 中に生成されることは一般的に知られている。生成した 色素は, メラノイジン色素と呼ばれ, ビール, 味そ, しょ う油, パンの耳，ご飯のおこげなどの色の原因物質の 1 つとして考えられている[1-5]. 当研究室では, 羊毛, 絹, ナイロンなどのポリアミド繊維と安価な還元糖(キシロー スやグルコースなど)を反応させることによって, 食品と 同様に, 繊維を黄色から茶褐色まで着色させることに成 功している $[6,7]$. 興味深いことに, 生成したメラノイジ ン色素は, 天然物由来の色素でありながら, 反応染料に 匹敵する高い染色堅ろう度を示すことも明らかにしてい る[7]. この原因として, 色素の原料である糖質が無色で あることに加えて, 生成したメラノイジン色素が䋊維上 に共有結合で導入されることが考えられる. タンパク質 繊維から形成されている牛革を用いた場合にも, メイラー ド反応によって着色され，同様に高い染色堅ろう度を示 すことを期待できる，そこで，本論文では，還元糖を用 いた牛革の着色反応について調べたので報告する. 図 1

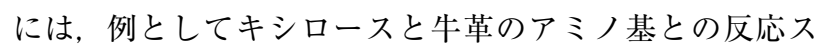
キームを示す.

\section{2. 実 験}

\section{1 試薬および牛革}

D-キシロース $(\mathrm{Xyl}), \mathrm{L}-$ アラビノース (Ara), D-グルコー ス (Glc)，D-ガラクトース (Gal)，D-マンノース (Man), お 

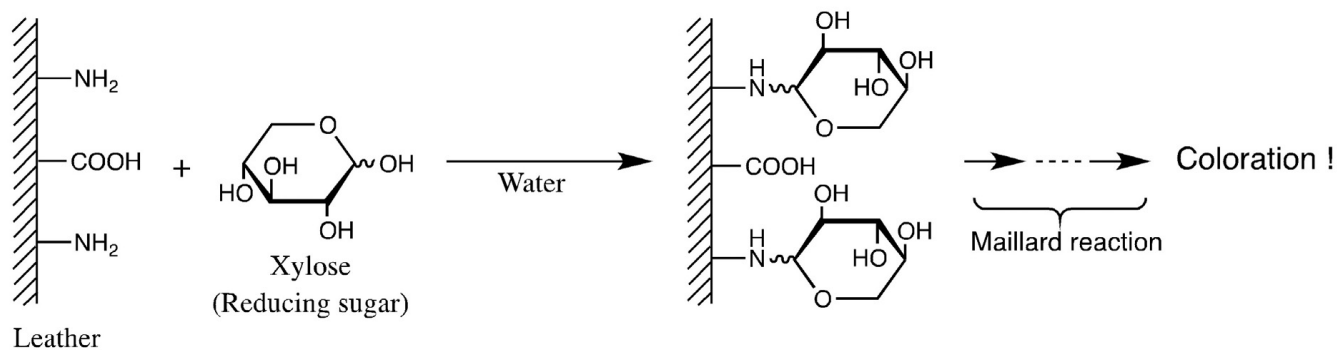

Fig. 1 Scheme of coloration reaction of chrome tanned leather by D-xylose.

よび D-マルトース一水和物 (Mal) の還元糖は, ナカライテ スク(株)より入手した。これらの還元糖はさらなる精製 を行わず実験に用いた，図 2 には，実験に用いた還元糖 の化学構造を示す。また, 反応に用いた水は水道水を蒸 留後，イオン交換樹脂によって脱イオン化したものを利 用した。クロムなめし済の牛革は，金丸油化工業(株)よ り入手し，乾燥を防ぐためにビニール袋内で保管したも の(含水率 : 約 45\%) を以下の実験に用いた.

\section{2 各種還元糖と牛革との反応}

$100 \mathrm{ml}$ マイヤーフラスコに，一定量の還元糖を入れ， $100 \mathrm{ml}$ の蒸留水に溶解させた (糖濃度 : $0.4 \mathrm{~mol} / \mathrm{l})$. 溶液が 目的の温度に達したことを確認後, 速やかに牛革 $(60 \mathrm{~mm} \times 30 \mathrm{~mm}$, 約 $1.8 \mathrm{~g})$ をフラスコの中に入れた。一定 時間加熱後, 牛革を取り出し, 蒸留水で十分洗浄し, 牛 革がわん曲しないように軽く荷重をかけてゆっくり自然 乾燥させた。

\section{3 牛革の色および収縮率の評価}

着色した牛革の銀 (おもて) 面の色濃度は積分球を装着 した紫外可視分光光度計 ((株)島津製作所製 UV-3100A) か ら得られた $450 \mathrm{~nm}$ での反射率より算出した K/S 值によっ て評価した，K/S 值は，布表面に固着した染料濃度に比例 する值として染色加工の分野で一般的に利用されている [8]. また，牛革の収縮率は，反応させた牛革の面積值を 未加工の牛革の面積值で割った值の百分率から算出し, 加熱による牛革の収縮を評価した。

\section{3. 結果と考察}

\section{1 キシロースによる牛革の着色および熱収縮}

はじめに，還元糖である D-キシロースと牛革との反応 について調べた。図 3 および図 4 は, 反応時間に対する 牛革の着色濃度 $(\mathrm{K} / \mathrm{S}$ 值)および熱による収縮率の変化を示 す． D-キシロースとの反応時間と共に K/S 值は大きくな り，これまでに報告したポリアミド繊維と同様に[6]，牛 革を着色することができた。ささらに，反応温度の影響に ついて調べたところ， $95^{\circ} \mathrm{C}$ および $100^{\circ} \mathrm{C}$ の高温条件では, 羊毛繊維を着色した系と同等の濃色 (茶褐色)を再現する ことができた，しかしながら，熱収縮率について調べる と, $90^{\circ} \mathrm{C}$ までは加熱による牛革の収縮はほとんど認めら れなかったが, $95^{\circ} \mathrm{C}$ および $100^{\circ} \mathrm{C}$ の反応条件では, 牛革 は著しく熱収縮を引き起こした。この収縮が始まる温度
は，日本皮革技術協会が発表しているクロムなめし革の 耐熱温度の範囲内にある (収縮開始温度 : 77〜 $120^{\circ} \mathrm{C}$ ) [9]. この資料によると，環境に配慮した植物タンニンでなめ した牛革であれば，より低温で熱収縮を起こす可能性が ある (収縮開始温度 : $70 \sim 89^{\circ} \mathrm{C}$ )。工業的に還元糖を利用し た着色技術を開発するためには，低温でもメイラード反 応を効率良く進行させる反応条件を検討する必要がある。 図 5 には, $95^{\circ} \mathrm{C}$ の反応条件で着色させた牛革の写真を示 す. 24 時間および 48 時間反応することによって, 熱収縮 を伴いながらも，牛革がカーキ色および茶色に着色され

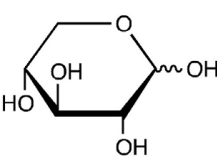

Xylose (Xyl)

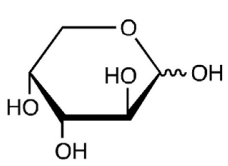

Arabinose (Ara)*

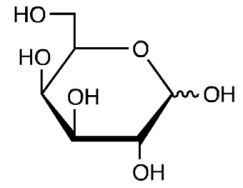

Galactose (Gal)
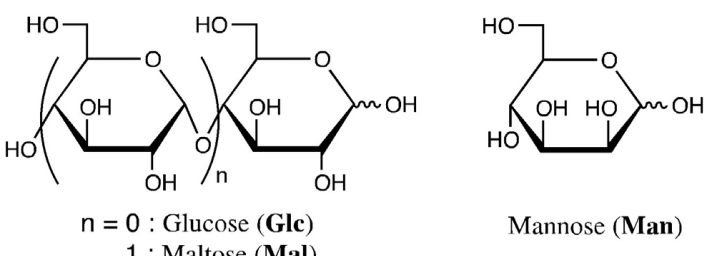

Mannose (Man)

* D-isomer

Fig. 2 Structures of reducing sugars used in this work.

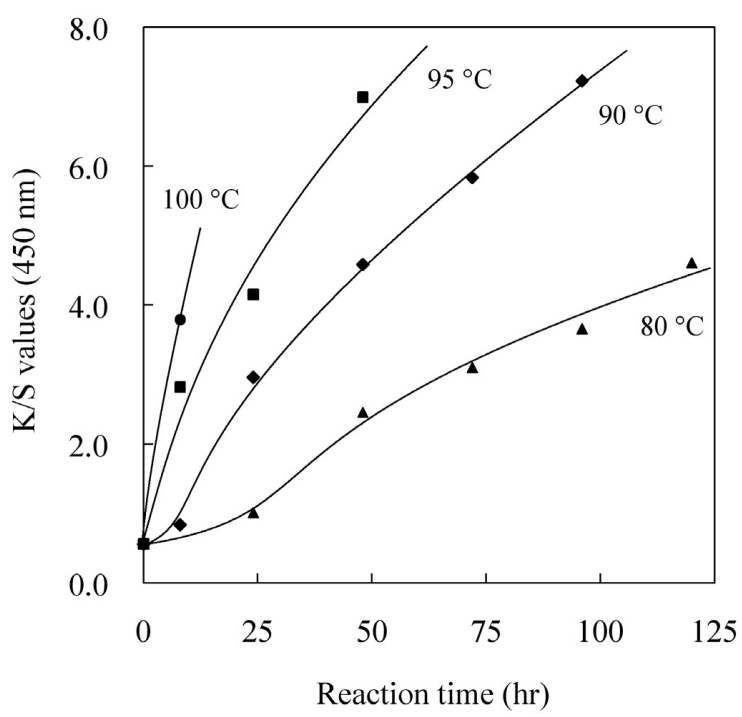

Fig. 3 Influence of the reaction temperature on $\mathrm{K} / \mathrm{S}$ values of chrome tanned leather sheets. Reaction conditions : $[$ xylose $]=0.4 \mathrm{~mol} / \mathrm{l}$. 


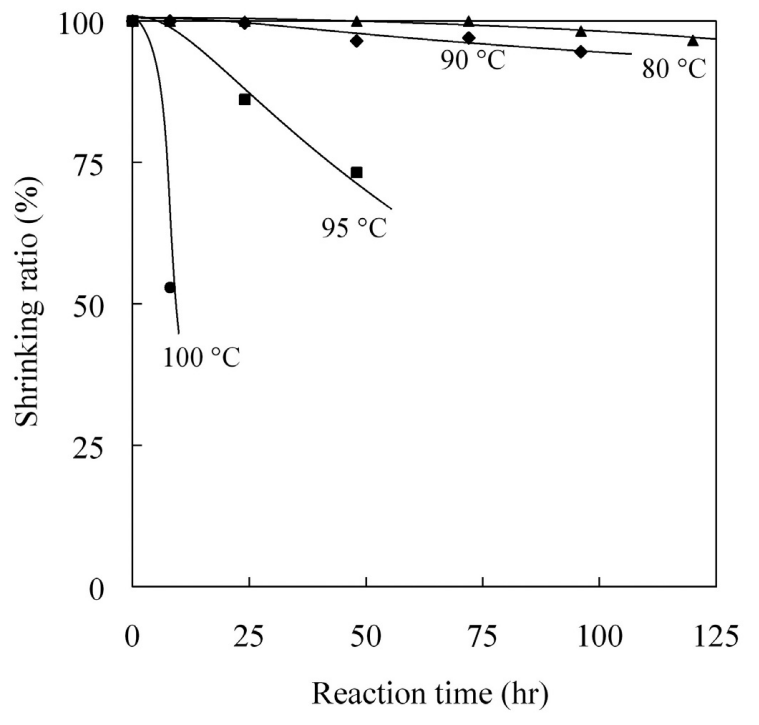

Fig. 4 Influence of the reaction temperature on shrinking ratio of chrome tanned leather sheets. Reaction conditions : $[\mathrm{xylose}]=0.4 \mathrm{~mol} / \mathrm{l}$.

\section{ることが確認できる}

\section{2 各種還元糖による牛革の着色}

次に, D-キシロース以外の還元糖を用いて同様の実験 を行った。ただし，反応温度を $90^{\circ} \mathrm{C}$ ，反応時間を 24 時 間に固定した．図6が示すように，いずれの還元糖を用 いた場合にも，D-キシロースと同様に牛革を着色するこ とができた．また，以前の報告と同様に[6]，分子量の小 さな還元糖で高い着色効果が認められた。具体的には, ペントース (単糖類, $\mathrm{C}_{5} \mathrm{H}_{10} \mathrm{O}_{5}$ ) >ヘキソース (単糖類, $\mathrm{C}_{6} \mathrm{H}_{12}$ $\left.\mathrm{O}_{6}\right)>$ 二糖類 $\left(\mathrm{C}_{12} \mathrm{H}_{22} \mathrm{O}_{11}\right)$ の順で高い反応性(着色効果)を示 した，検討した中では，ペントースである L-アラビノー スで最も高い着色効果が得られた。

\section{4. まとめ}

本研究では, クロムなめしを行った牛革と還元糖を反 応させることによって，これまでに検討したポリアミド 瀻維と同様に, 黄色から茶色まで牛革を着色することが できた．しかしながら， $95^{\circ} \mathrm{C}$ 以上の高温条件での加熱で は, 牛革の大きな熱収縮が起こり, 逆に, $90^{\circ} \mathrm{C}$ 以下の反 応条件では, 着色に長い反応時間を要することも明らか となった，今後の研究では，低温でメイラード反応を進 行させる着色方法, あるいは, 熱収縮を抑制できる着色 方法の開発を進める必要がある.ささらに, 以前の報告で, メイラード反応で着色させた羊毛瀻維が, 汗, 洗濯, 摩 擦に対する高い染色堅ろう度を示したことから, 着色後 の牛革の染色堅ろう度についても調べる必要がある。

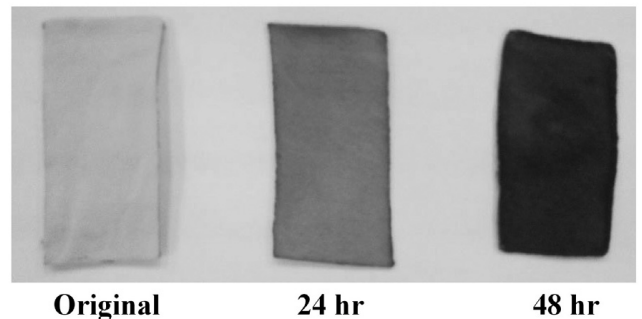

Fig. 5 Photograph of chrome tanned leather sheets reacted with xylose. Reaction conditions : [xylose] $=0.4 \mathrm{~mol} / 1,95^{\circ} \mathrm{C}$.

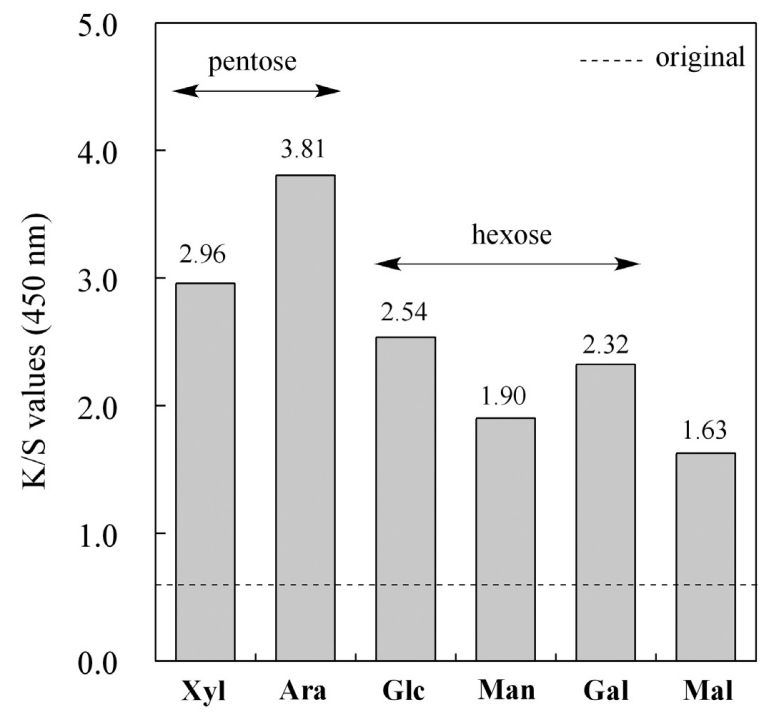

Fig. 6 Influence of sugar structure on $\mathrm{K} / \mathrm{S}$ values of chrome tanned leather sheets. Reaction conditions : $90^{\circ} \mathrm{C}, 24 \mathrm{hr}$, [sugar] $=0.4 \mathrm{~mol} / 1$.

\section{文 献}

1. J. E. Hodge, J. Agric. Food Chem., 1, 928 (1953).

2. Y. Tomoda, M. Nakamura, and Y. Yoshihiro, University of Tokyo Seisan Kenkyu, 7, 37 (1955).

3. S. H. Ashoor and J. B. Zent, J. Food Sci., 49, 1206 (1984).

4. J. M. Ames, Food Chem., 62, 431 (1998).

5. S. Sasaki, Y. Shirahashi, K. Nishiyama, H. Watanabe, and F. Hayase, Biosci. Biotechnol. Biochem., 70, 2529 (2006).

6. T. Ohe and Y. Yoshimura, Text. Res. J., 84, 539 (2014).

7. T. Ohe, Y. Yoshimura, and Y. Shimada, Kagaku to Kogyo, 88, 89 (2014).

8. P. K-F. Munk, Z. Tech. Physik., 12, 593 (1931).

9. Website of "Japanese Association of Leather Technology" (http : //www.hikaku-kyo.org/). 